\title{
Real Estate Investment as a Panacea for Economic Instability in Nigeria: Evidence from Northeastern States of Nigeria
}

\author{
Muhammad Umar Bello ${ }^{1}$, Aliyu Ahmad Aliyu ${ }^{1}$, David Martin @ Daud Juanil ${ }^{2}$, Rozilah Kasim ${ }^{2}$ \\ ${ }^{1}$ Abubakar Tafawa Balewa University \\ Tawafa Belewa Way, P. M. B. 0248, Bauchi, 740272, Nigeria \\ ${ }^{2}$ Universiti Tun Hussein Onn Malaysia \\ 101 Parit Raja, Batu Pahat, Johor, 86400, Malaysia
}

DOI: $10.22178 /$ pos.25-1

JEL Classification: L85, R3

Received 14.07.2017

Accepted 10.08.2017

Published online 16.08.2017

Corresponding Author: Muhammad Umar Bello, mubello78@gmail.com

(c) 2017 The Authors. This article is licensed under a Creative Commons Attribution 4.0 License (ब) (1)

\begin{abstract}
Real estate investment is an emerging business in many countries of the world. Real estate investment was thoroughly investigated to come up with solution faced by the transaction of land and building. Real estate investment is strictly related to the housing price. It has been pointed out by many researchers that the housing price is affected by many factors, such as interest rate, land supply, government policies and inflation rate. The research highlighted most important aspects of the outcomes. An increase in international real estate capital flows could foster increasing demand for stronger institutions across a global real estate market. The method adopted in this research was quantitative through which 100 questionnaires were developed and distributed within the study area (Bauchi, Gombe, Adamawa and Yobe States). The simple percentage was used to analyzed the data collected. The research is exploratory in nature; hence, a non-probability purposive sampling technique was used for the study. The finding of the research vindicated that real estate investment has a significant role in sharpening the economy of the region, and also the findings revealed that real estate investment opportunity is huge. And again for suggested that housing provision cannot be realized only by private individual excerpts through government intervention. The study concludes that real estate investment, if explore it will create a reliable return to the investment owners, the benefits that can be derived from real estate investment, has been revealed by this study. The study also highlighted that private developers are key important for real estate investment in Nigeria. The conclusion drawn by this research shows that real estate investment has a capacity of transforming economic hardship in the country.
\end{abstract}

Keywords: real estate investment; land; speculator; developer; projects.

\section{INTRODUCTION}

Real estate investment is among the key investment that enables the investor to recover his investment as at when due $[2,8,10,24]$. For any investment to flourish one has to make any aspect of the business feasibility and viability studies for proper dealings and carefulness from avoiding fraudulent business, real estate business has less harm if the owner or the buyer makes a proper investigation of the subject matter. An increase in international real estate capital flows could foster increasing demand for stronger institutions across global real estate market [2, 13, 28, 31, 37]. A number of article have argued that real estate investment has realized tremendous positive abnormal risk adjustment returns [13], return on real estate investment is certain as rent or prestige as indicated by [32]. Sale or lease of parcel of land by a speculator or prospective seller to willing buyer entails good returns to the seller and asset possession to the willing buyer. Another good aspect of investment on real estate is tenants selection [18, $29,6,40,38,7,28,31,37]$. 
However, real estate investment is strictly related to the housing price. It has been pointed out by many researchers that the housing price is affected by many factors, such as interest rate, land supply, government policies and inflation rate $[4,19]$. A major part of this research is concentrated on the solution to economic hardship when investing in real estate, in order word economic viability of real estate investment. More again, recent urbanization of Nigerian cities also help in real estate returns through rent and sale of houses $[34,43]$. While a great deal of attention is given to real estate investment policies worldwide concerned with such areas as forest management, coastal zone management, environmental sustainability and managing the urban environment, less attention is given to the infrastructures which facilitate the implementation of the associated policies and programs $[5,9,11$, 36]. While positively much is known about the economic and social implication of real estate investment among the populace of urban and cities centers in Nigeria [14]. Even though, the processes involved in marketing survey for prospective buyers are many, this may be through registered estate agents, real estate brokers or real estate neighbours.

\section{Real Estate Investment Dimension}

As indicated above that real estate investment has been condoned globally as an aspect of investment with very minimal risk [16, 17, 41]. Real estate investment create employment to citizen and beautified new cities [44]. The dimension postulated by real estate investment is regulated by law of supply and demand [26]. Housing provisioning is the key factor to determine how successful an economy is. Adoption of real estate investment by private organisations elevates the level of an economy, it has been recorded that real estate investment helps in promoting decent living in Nigeria [31, 32].

Real estate investment go hand in hand with stock market in providing shareholders with a lot of benefits and creation of entrepreneurship [4, 20]. The main method of conveying real estate investment has been through leasing, selling and mortgaging [27]. Leasing has safeguarded cities' regulation over type of land use and semi-urban and urban development, also in the forthcoming. Maintaining the planning regulations in the hands of professionals' town planners has tremendous advantage in sanitizing urbanization.

\section{MATERIALS AND METHODS}

Primary data was employ through structure questionnaire was used to fetch information. From 100 respondents who were private developer within Bauchi, Gombe, Adamawa and Yobe States. Simple percentage was used to analyzed the data collected. This research is exploratory in nature; hence, a non-probability purposive sampling technique was used for this study as is in line with the work of [12]. A total of 100 questionnaires (25 questionnaires for each State) were distributed to private developers in Bauchi, Gombe, Adamawa and Yobe States. Such States were chosen partly for convenience sake. The questions were a mixture of open ended and close ended questions (Figure 1).

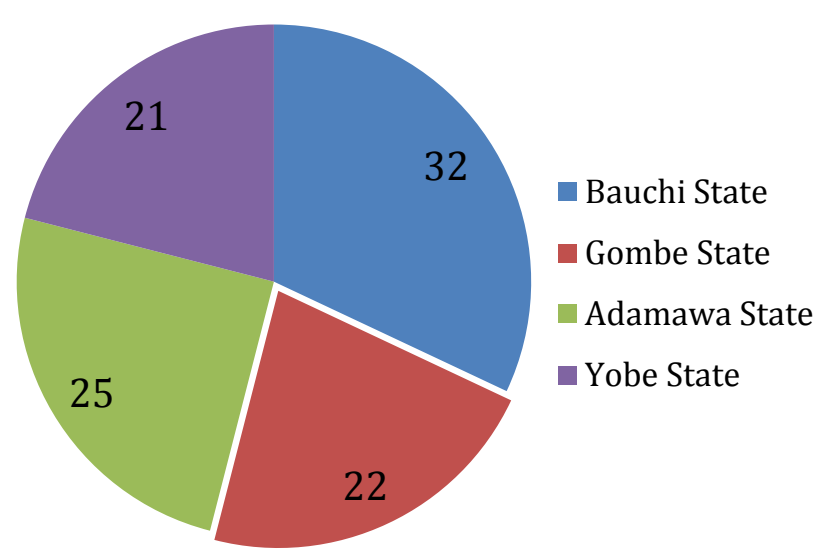

Figure 1 - Percentage of Questionnaire retrieved from Study Area

From the Figure 1 Bauchi states has the largest number of respondents with $32 \%$, then followed by Adamawa State with $25 \%$, followed by Gombe State with $22 \%$ and the lowest was Yobe State with $21 \%$. These shows that private developer in Bauchi State are more of up and doing than other States in Study area.

Figure 2 above revealed none of States reached $50 \%$ of their projects completion which shows that a striding efforts needs to be concerted so that housing should be adequate in the country. Only Adamawa State has the highest percentage of projects completion within the duration of this study, followed by Bauchi State with $30 \%$, Gombe State $18 \%$ and Yobe State $12 \%$. 


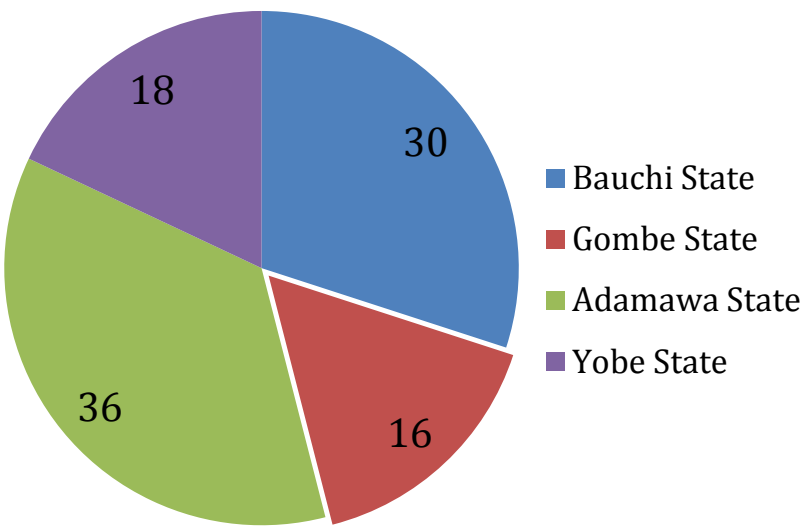

Figure 2 - Percentage of Properties developed within 2014-2016 in the study Area

\section{RESULTS AND DISCUSSION}

Findings of this research revealed that up till now there is low pace for projects completion in Nigeria due to numerous factors, this are in relation with the work of $[23,36]$. It was understood that Nigerian property market was the best in the African sub-region but lack adequate records [42, 35]. As such, housing provision for all would be of great difficult as reiterated by [15]. Real estate investment in most of this States shows that viability of the business is not fast coming as indicated in Latvia by [22], the real estate investment owners in the study area are confronted with many problems such as, high price of building materials, tenants selection, government policies, fraudulent land transaction, etc. as revealed in [4, 25]. It was gathered in this research that real es- tate investment in the study area contributes in housing provision as revealed in [35]. The percentage of the developed projects shows the viability of real estate investment in Nigeria as indicated by [1] and [33]. But study by [39] suggested that housing provision cannot be realized only by private individual excepts through government intervention. However, this assertion is against $[3,6,30,32]$. Relatively, the outcomes of this research revealed that real estate investment has opportunity of providing employment to many unemployed youth this proclamation is in agreement with the work of [21].

\section{CONCLUSION}

This research study concludes that real estate investment if explore it will create reliable return to the investment owners, the benefits that can be derived from real estate investment has been revealed by this study. This study has shown that government policy should be enacted to create more viability to the business. The study also postulated that economy of a nation can be enhanced if property markets are well coordinated. It also concluded that building materials should be manufactured locally so that the cost would be minimize. The study also highlighted that private developers are key important for real estate investment in Nigeria. The conclusion drawn by this research shows that real estate investment has a capacity of transforming economic hardship in the country.

\section{REFERENCES}

1. Adeoye, D. O. (2016). Challenges of Urban Housing Quality: Insights and Experiences of Akure, Nigeria. Procedia - Social and Behavioral Sciences, 216, 260-268. doi: 10.1016/j.sbspro.2015.12.036

2. Agbola, T. (1994). The Prospect for Private Sector Involvement in urban management function in Nigerian. Review of Urban \& Regional Development Studies, 6(2), 135-149. doi: 10.1111/j.1467940X.1994.tb00054.x

3. Akkoyun, 0. (2012). Simulation-based investment appraisal and risk analysis of natural building stone deposits. Construction and Building Materials, 31, 326-333. doi: 10.1016/j.conbuildmat.2012.01.003

4. Amidu, A.-R., \& Aluko, B. T. (2006). Performance Analysis of Listed Construction and Real Estate Companies in Nigeria. Journal of Real Estate Portfolio Management, 12(9), 177- 186. doi: 10.5555/repm.12.9.p0544q8560117x60 
5. Anaafo, D. (2015). Land reforms and land rights change: A case study of land stressed groups in the Nkoranza South Municipality, Ghana. Land Use Policy, 42, 538-546. doi:

10.1016/j.landusepol.2014.09.011

6. Armonat, S., \& Pfnuer, A. (2004). Asset allocation versus entrepreneurial decisions in real estate investment. Briefings in Real Estate Finance, 4(2), 131-146. doi: 10.1002/bref.128

7. Bello, M. U., Aliyu, A. A., \& Alhaji, M. U. (2015). Women participation in housing Delivery: Bauchi Metropolis in Perspective. Proceedings of The International Academic Conference for Sub-Sahara African Transformation \& Development, 3(5), 495-503.

8. Benfield, M. W. (1970). The effect of credit regulation on real estate transactions. The Business Lawyer, 25(2), 501-510.

9. Boanada-Fuchs, A. (2015). The politics of land- Selective government reforms in Gujarat. Geoforum, 65, 209-212. doi: 10.1016/j.geoforum.2015.07.030

10. Braimoh, A. K., \& Onishi, T. (2007). Spatial determinants of urban land use change in Lagos, Nigeria. Land Use Policy, 24(2), 502-515. doi: 10.1016/j.landusepol.2006.09.001

11. Caruso, G., Cavailhes, J., Peeters, D., Thomas, I., Frankhauser, P., \& Vuidel, G. (2015). Housing land transaction data and structural econometric estimation of preference parameters for urban economic simulation models. Data in Brief, 5, 447-452. doi: 10.1016/j.dib.2015.09.047

12. Dodo, M. (2014). The application of health and safety plan in Nigerian construction firms. Jordan Journal of Civil Engineering, 8(1), 81-87.

13. Eichholtz, P. M. A., Gugler, N., \& Kok, N. (2011). Transparency, Integration, and the Cost of International Real Estate Investments. The Journal of Real Estate Finance and Economics, 43(12), 152-173. doi: 10.1007/s11146-010-9244-5

14. Famoriyo, S. (1984). Administration of land allocation in Nigeria. Land Use Policy, 1(3), 217-224. doi: 10.1016/0264-8377(84)90065-6

15. Freytag, A., \& Fricke, S. (2017). Sectoral linkages of financial services as channels of economic development - An input-output analysis of the Nigerian and Kenyan economies. Review of Development Finance, 7(1), 36-44. doi: 10.1016/j.rdf.2017.01.004

16. Gates, C. (1989). The historical role of political economy in the development of modern Lebanon. Oxford: Centre for Lebanese Studies.

17. Hafez, R. M. (2015). New cities between sustainability and real estate investment: A case study of New Cairo city. HBRC Journal, 13(1), 89-97. doi: 10.1016/j.hbrcj.2015.03.001

18. Hartzell, J. C., Sun, L., \& Titman, S. (2006). The Effect of Corporate Governance on Investment: Evidence from Real Estate. Real Estate Economics, 34(3), 343-376. doi: 10.1111/j.15406229.2006.00170.x

19. Hui, E., Yu, C., \& Ip, W.-C. (2010). Jump point detection for real estate investment success. Physica A: Statistical Mechanics and its Applications, 389(5), 1055-1064. doi: 10.1016/j.physa.2009.11.022

20. Hyötyläinen, M., \& Haila, A. (2017). Entrepreneurial public real estate policy: The case of Eiranranta, Helsinki. Geoforum, 1-8. doi: 10.1016/j.geoforum.2017.04.001

21. Kauko, T. (2004). Towards Infusing Institutions and Agency into House Price Analysis. Urban Studies, 41(8), 1507-1519. doi: 10.1080/0042098042000226975

22. Kauškale, L., \& Geipele, I. (2017). Integrated Approach of Real Estate Market Analysis in Sustainable Development Context for Decision Making. Procedia Engineering, 172, 505-512. doi:

10.1016/j.proeng.2017.02.059

23. Ke, Q., Jayne, M., \& Isaac, D. (2009). Sole agency vs multi-agency: an investigation of agency practice across England and Wales. Property Management, 27(4), 228-241. doi:

10.1108/02637470910979998 
24. Kobbinah, P., Erdiaw-Kwasie, M. O., \& Amoateng, P. (2015). Rethinking sustainable development within the framework of poverty and urbanisation in developing countries. Environmental Development, 13, 18-32. doi: 10.1016/j.envdev.2014.11.001

25. Liang, Y., \& McIntosh, W. (1998). REIT style and performance. Journal of Real Estate Portfolio Management, 4(1), 69-78. doi: 10.5555/repm.4.1.v8481570845188q7

26. Liu, G., \& Zheng, Q. (2011). An Empirical Study of the Relationship between Urbanization and the Real Estate Investment in China. Advanced Materials Research, 361-363, 1099-1104. doi: 10.4028/www.scientific.net/AMR.361-363.1099

27. Low, S., Donovan, G. T., \& Gieseking, J. (2011). Shoestring Democracy: Gated Condominiums and Market-Rate Cooperatives in New York. Journal of Uban Affairs, 34(3), 279-296. doi: 10.1111/j.1467-9906.2011.00576.x

28. Mabogunje, A. L. (2010). Land Reform in Nigeria: progress, problems \& prospects. Retrieved from http://siteresources.worldbank.org/EXTARD/Resources/336681-1236436879081/58933111271205116054/mabogunje.pdf

29. Marrison, C. (2008). Advances in Quantifying Risk in Commercial Real Estate Lending. Briefings in Real Estate Finance, 5(3-4), 135-142. doi: 10.1002/bref.161

30. Ogu, V. I., \& Ogbuozobe, J. E. (2001). Housing policy in Nigeria : towards enablement of private housing development. Habitat International, 25(4), 473-492. doi: 10.1016/s01973975(01)00018-2

31. Olaleye, A. (2008). Property market nature and the choice of property portfolio diversification strategies: The Nigeria experience. International Journal of Strategic Property Management, 12(1), 35-51. doi: 10.3846/1648-715X.2008.12.35-51

32. Olawande, O. A. (2011). Harnessing real estate investment through proper tenant selection in Nigeria. Property Management, 29(4), 383-397. doi: 10.1108/02637471111154827

33. Olayiwola, L., Adeleye, O., \& Jiboye, A. (2006). Effect of Socio-Cultural factors on Housing Quality in Osogbo, Nigeria. In International Symposium on Construction in developing Economies: New Issues and Challenges.

34. Onibokun, A. G., Agbola, T., \& Labeodan, O. (1989). World Bank assisted sites-and-services projects: Evaluation of Nigeria's experiment. Habitat International, 13(3), 51-64. doi: 10.1016/01973975(89)90020-9

35. Onwuanyi, N., \& Oyetunji, A. K. (2016). Revitalizing Nigeria's built heritage using Facility Management service delivery: The Lagos National Arts Theatre Complex. International Journal of Sustainable Built Environment, 5(2), 579-586. doi: 10.1016/j.ijsbe.2016.05.001

36. Osmond, I. C., Adesiyan, O. S., Olusola, A. M., \& Daniel, D. O. (2015). Towards an Effective Real Estate Agency Education: A Stride to Efficiency in Nigeria. Procedia - Social and Behavioral Sciences, 191, 2687-2692. doi: 10.1016/j.sbspro.2015.04.360

37. Price, B., Kienast, F., Seidl, I., Ginzler, C., Verburg, P. H., \& Bolliger, J. (2015). Future landscapes of Switzerland: Risk areas for urbanisation and land abandonment. Applied Geography, 57, 32-41. doi: 10.1016/j.apgeog.2014.12.009

38. Rashid, I. M., Abu Bakar, N., \& Razak, A. (2016). Determinants of Foreign Direct Investment (FDI) in Agriculture Sector Based on Selected High-income Developing Economies in OIC Countries: An Empirical Study on the Provincial Panel Data by Using Stata, 2003-2012. Procedia Economics and Finance, 39, 328-334. doi: 10.1016/S2212-5671(16)30331-8

39. Reddy, K. P. (2012). BIM for building owners and developers : making a business case for using BIM on projects. Hoboken: Wiley.

40. Roux, L. P., \& Dongelmans, D. (2013). Added Value of Hospitality Management in the Evolution of Property and Facility Management. In Proceedings of the 20th Annual European Real Estate 
Society Conference. Retrieved from

https://eres.architexturez.net/system/files/pdf/eres2013_292.content.pdf

41. Sakr-Tierney, J. (2017). Real estate, banking and war: The construction and reconstructions of Beirut. Cities, 69, 73-78. doi: 10.1016/j.cities.2017.06.003

42. The Nigerian Institution of Estate Surveyors and Valuers. (2017). Blog. Retrieved July 10, 2017, from http://www.niesv.org.ng/niesv_blog.php

43. Williamson, I. P. (2001). Land administration "best practice" providing the infrastructure for land policy implementation. Land Use Policy, 18(4), 297-307. doi: 10.1016/S0264-8377(01)00021-7

44. World Bank. (2015, June). Lebanon: Promoting poverty reduction and shared prosperity: a systematic country diagnostic. Retrieved from

http://documents.worldbank.org/curated/en/698161468179049613/pdf/97498-CASP151430-SecM2015-0202-IFC-SecM2015-0073-MIGA-SecM2015-0047-Box391476B-OUO9.pdf

\section{APPENDICES}

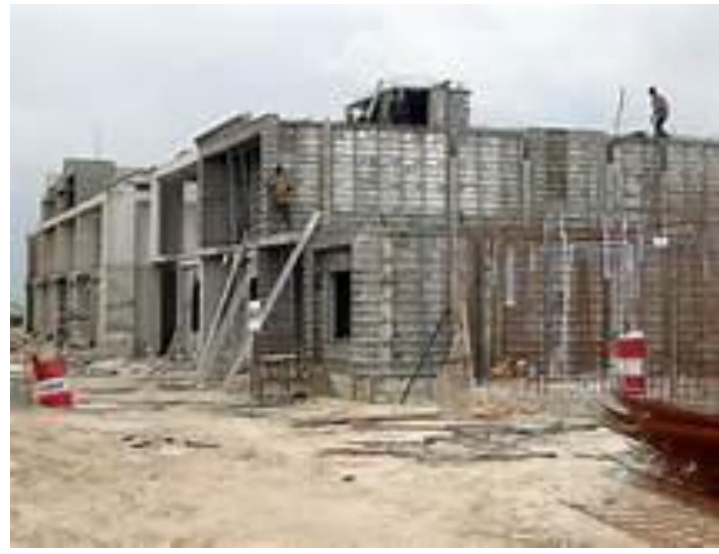

Figure A.1- Building sites in Bauchi

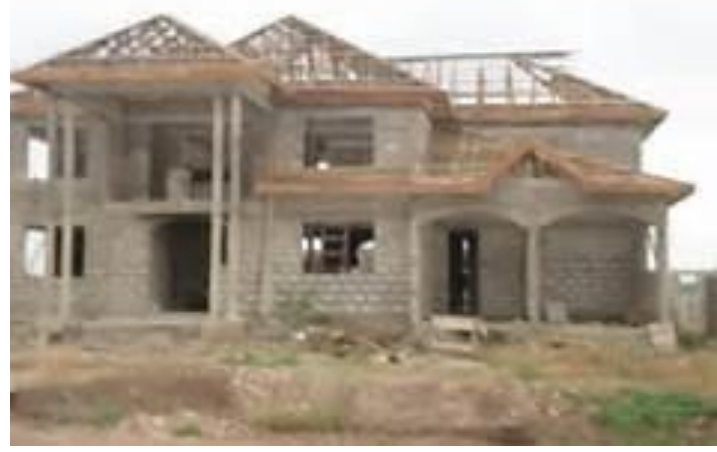

Figure A.3 - Building Sites Yola, Adamawa

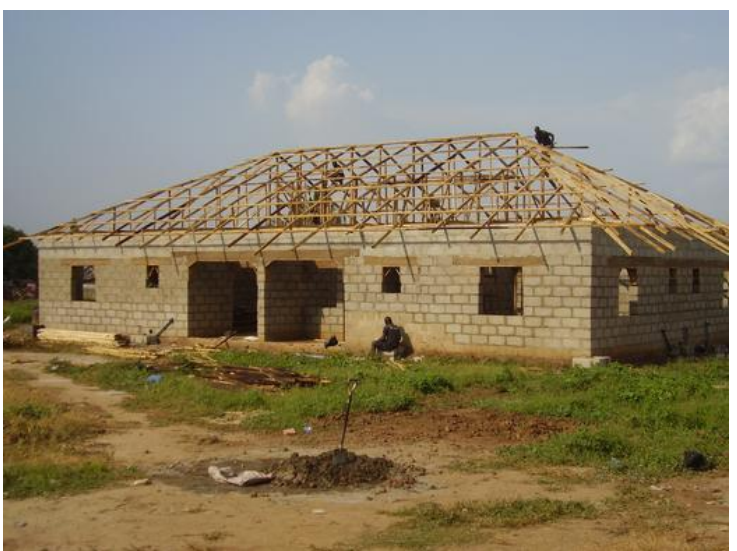

Figure A.2 - Building sites in Gombe

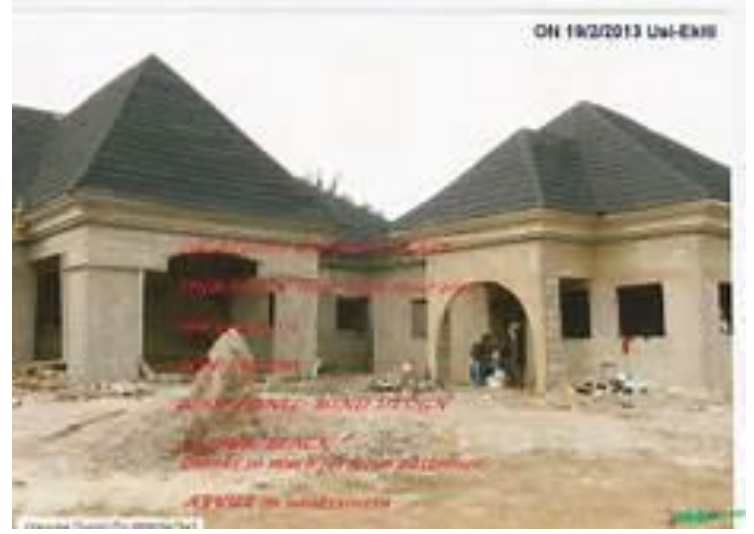

Figure A.4 - Building Site in Damaturu, Yobe State 